\title{
AKKOYUNLULAR VE ERZINCAN (Uzun Hasan Devrine Kadar)
}

\begin{abstract}
Yrd. Doç. Dr. Ahmet TOKSOY*
ÖZ: Doğu Anadolu'da önemli bir geçiş bölgesi olan Erzincan, İlhanlı Devleti'nin çöküşünden sonra Doğu Anadolu'da gelişen önemli hadiselere sahne olmuştur. Timur'un Anadolu üzerine yaptığı akınlar sirasında Erzincan'1 elinde bulunduran Mutahharten, onun Anadolu'dan ayrılmasından sonra Akkoyunlu Türkmenleriyle mücadele etmiştir. Akkoyunlular bu mücadelelerden sonra Erzincan'1 ele geçire bilmek için ciddi bir uğraş vermişler ve sonunda da ele geçirmişlerdir.

Anahtar Kelimeler: Bayındır, Ahmed Bey, Kara Yülük Osman Bey, Karakoyunlu, Kara Yusuf

\section{Akkoyunlu and Erzincan}

\section{(Uzun Hasan Until the Period)}

ABSTRACT: As an important transition region, Erzincan had witnessed two important events in Eastern Anatolian region after the collapse of Ilhanid State. Mutahharten, possessing Erzincan during Tamerlane raids towards Anatolia, had fought against Aqqoinid Turcomans after Tamerlane had left Anatolia. AqqoinidState had struggled a lot to capture Erzincan after those fights and at the end they had managed to do this.
\end{abstract}

Key Words: Bainder, Ahmed Bey, Kara Yülük Osman Bey, Qaraqoinid, Kara Yusuf

Akkoyunlular, Tur Ali Bey'in ölümünden sonra, Bayındırlı Türkmenlerinin başına geçen Kutlu Bey döneminde Bayburt-Erzincan bölgesinin güneyine doğru gelişmeye başladılar. Bölgede güçlenmeye başlayan Kutlu Bey, Erzincan yöneticilerinin Eratnalılarla

\footnotetext{
* RTE Üni. Eğitim Fak. Sosyal Bilgiler Eğitimi ABD, ahmet.toksoy@erdogan.edu.tr
} 
anlaşmazlıklarında Erzincan beylerini destekledi. Bu politikası icabı olarak Kutlu Bey, 1379'da Eratnalı ordusunun Erzincan'1 sıkıştırması üzerine oğlu Ahmed komutasında gönderdiği kuvvetlerle Mutahharten'e askeri yardımda bulundu (Esterabadî 1928: 163; Woods 1993: 76-77). Daha sonra Akkoyunlu hükümdarı Kutlu Bey’in ölümü üzerine, Bayındırlıların başına oğlu Ahmed Bey geçti.

Kutlu Bey'in sağlığında Akkoyunlu başbuğlarının en büyükleri olan oğulları Ahmed Bey Palu'ya, Pîr Ali Kiğı'ya, Kara Yülük Osman Bey ise Ergani'ye hâkim bulunuyordu (Cöhçe 1997: 125). Ahmed Bey'in Bayındırlıların başına geçmesinden istifade etmek isteyen Erzincan Emiri Mutahharten daha önce Bayındırlılarla yaptığı anlaşmayı bozarak düşmanca tavır takınmaya başladı. Esasen Mutahharten'in bölgede iktidarını koruyabilmek için zaman zaman yardımlarına başvurduğu bu Türkmen topluluğu ile Kutlu Bey zamanında başlayan iyi ilişkiler dönemi böylece sona ermiş oldu (Yücel 1991: 271). Erzincan Emirinin Bayındırlıların üzerine saldırıp mallarını yağmalaması, Ahmed Bey'i harekete geçirdi. Nihayet kalabalık bir orduya sahip olan Bayındırlılar, fevkalade karşı bir hamle ile Mutahharten'i ağır bir yenilgiye uğrattılar. Bir müddet sonra Erzincan emiri, uğradığı bu utandırıcı mağlubiyetin tesirini giderebilmek için yayladan inmekte olan Akkoyunlu Türkmenlerine tekrar tecavüze yeltendi ise de Türkmenlerin üstün kuvvetleri karşısında muharebeyi kabul etmeyerek barış için Çemişkezek emiri Yelman'1 ricac1 gönderdi (Esterabadî 1928: 369; Yücel 1991: 271272).

Erzincan emirinin bu tereddütlü halini gören Türkmenler, onu yalan vaatlerle oyalayarak, nihai darbeyi vurabilmek için askeri hazırlıklara başladılar. Hazırlıklar tamam olunca da Mutahharten'in üzerine yüklenip mağlup ettikten başka, kendisini Karakoyunlu Türkmenlerinden yardım istemek zorunda biraktılar. Öteden beri Akkoyunlular ile rekabet halinde olan Karakoyunluların başbuğu Kara Mehmed, ortak düşmana karşı birlikte savaşmayı kabul etti. Mutahharten ve müttefiki Kara Mehmed dar bir geçitte Akkoyunluları sıkıştırarak bozguna uğrattılar. $\mathrm{Bu}$ olaydan sonra Akkoyunlular Sivas hükümdarı Kadı Burhan ed-Dîn'e iltica ettiler (Esterabadî 1928: 369-370; Yücel 1991: 272).

Erzincan emîri Mutahharten, Kara Mehmed'in ölümünden sonra da Karakoyunlularla ittifakını devam ettirdi ve Bayındırlılarla uğraşmaya devam etti. Hatta 1389 'da Kara Mehmed'in ölümünden sonra 
TÜBAR-XXXV / 2014-Bahar / Akkoyunlular ve Erzincan

Karakoyunluların başbuğu olan Kara Yusuf', Akkoyunlu topraklarına taarruz için Mutahharten'e elçi gönderdi. Teklifi olumlu karşılayan Mutahharten geniş çapta savaş hazırlıklarına başladı. Erzincan emiri Misır Hoca, Sa'adlu boyu beyleri ile Karakoyunluların bütün diğer beylerine de mektuplar göndererek onların da yardımını sağlamaya çalıştı. Nihayet yapılan savaşta müttefikler mağlup olup Endires'te ${ }^{2}$ Kara Yusuf tutsak oldu ve Mutahharten ise kaçarak güçlükle Erzincan'a ulaşmayı başardı (Tihranî 1993: 36-37; Andreasyan 1975: 86). Bu mağlubiyetin zararlarını tek başına telafi etmek isteyen Erzincan emiri, Şamsat (Samsat) ${ }^{3}$ ta tekrar savaş hazırlığına başladı. Nihayet Murat 1rmağı kıyısında Gülüşkerd'de iki taraf arasında yeniden şiddetli bir savaş vuku buldu. Nehrin bir yakasında Mutahharten, öteki yakasında ise Akkoyunlu Ahmet Bey mevzi almıştı. Mutahharten, Ahmed Bey'in kızı ile evli olduğu için kayın pederi onunla sulh yapmak amacında idi. Fakat Ahmed Bey'in kardeşi Kara Yülük Osman Bey bunu kabul etmeyerek savaşa başladı. Mutahharten ikinci defa ağır mağlubiyete uğradı (Tihranî 1993: 37-38; Yücel 1991: 273-274).

Barlas-1 Türkîlerden Timur'un 1393/1394 Anadolu seferinde bölgeye gelmesi üzerine Mutahharten Sivas hükümdarı Kadı Burhan edDin'e karşı düşmanca bir tutum içine girdi. Emir Timur'un bölgeden ayrılması üzerine, Kadı Burhan ed-Dîn, kendisine karşı düşmanca bir tutum gösteren Mutahharten'i cezalandırmaya karar verdi. Bunun üzerine Akkoyunlu başbuğu Ahmed Bey, Sivas hükümdarına elçi göndererek kendisi ile birlikte hareket etmek istediğini bildirdi. $\mathrm{O}$, bu hareketiyle bir yandan Kadı Burhan ed-Dîn ile eski dostluğunu ihya edeceğini düşünürken diğer yandan da Karakoyunlular ile birleşerek Bayındırlılara karşı giriştiği düşmanca hareketlerinden dolayı esasen kin duyduğu damadı olan Mutahharten'i cezalandırmak istemiş olmalıdır. Nihayet Ahmed Bey, Erzincan hududunda Kadı Burhan ed-Dîn Ahmed'e katıldı. $\mathrm{Bu}$ seferden sonra Akkoyunlu başbuğuna Bayburt'a kadar olan bölgeyi ikta olarak verdikten sonra Sivas'a döndü (Esterabadî 1928: 476-477; Yücel 1991: 278-279; Cöhçe 1997: 124). Böylelikle Akkoyunlular belki de anayurtları olan bölgeye resmen yeniden yerleşmiş oldular (Woods 1993: 79).

1 Kara Yusuf hakkında bilgi için bk. Mahmud İsmayilov, Kara Yusuf, Bakü 1991

2 Şimdiki Suşehri.

3 Palu'nun batısında ve Murat ırmağı kıyısındadır. 
Kadı Burhan ed-Dîn'in 1398 'de ölümünden ${ }^{4}$ sonra Erzincan emiri rahat bir nefes aldı. Esasen bu ölüm Erzincan ile Bayındırlılar arasında var olan düşmanca hareketlerin bitip dostça ilişkiler kurmasına yol açtığ gibi öte yandan da, Mutahharten ile Osmanlı hükümdarı I. Bayezid arasında rekabetin başlamasına neden oldu. Kadı Burhan ed-Dîn'in ölümünden sonra devlet erkânı oğlu Âlâ ad-Dîn Ali Çelebi'yi hükümdar ilan ederek Sivas'1 Akkoyunlu Kara Yülük Osman Bey'e teslim etmediler. $\mathrm{Bu}$ durum karşısında Osman Bey, şehri şiddetli bir şekilde muhasara altına aldı. Direnme gücünü yitirmeye başlayan Sivaslılar, Osmanlı hükümdarı I. Bayezid'e haber göndererek şehri teslim almasını istediler. $\mathrm{Bu}$ teklifi kabul eden Yıldırım Bayezid, oğlu Süleyman Çelebi'yi emri altındaki kuvvetlerle gönderdi. Yapılan savaşta mağlup eden Osman Bey, Erzincan'a iltica etmek zorunda kaldı (Tihranî 1993: 46; Müneccimbaş1 1285:154-156; Yücel 1991: 287).

Erzincan emiri, Kara Yülük Osman Bey'i büyük bir hürmet ile karşıladı. Mutahharten'in esas gayesi Akkoyunlu başbuğunu, Sivas'1 ele geçirerek doğuya doğru yayılma eğilimi gösteren Osmanlı sultanı I. Bayezid'e karşı kullanmaktı. Osmanlı hâkimiyetinin Sivas'a kadar genişlemesi Erzincan Emirliğini bu devletle sınırdaş yaptı. Bundan dolayı da Mutahharten, emirliğinin batı ve kuzey sınırlarında meydana gelen bu siyasi gelişmeleri çok dikkatle takip etmek zorundaydı (Yücel 1991: 287). Ancak ne var ki, Kara Yülük Osman Bey, Mutahharten'in hizmetinde fazla kalmadı ve Memlûk Sultanına başvurdu. Osman Bey'in bu isteği sultan Berkuk tarafından memnuniyetle kabul edildi (Tekindağ 1961: 91). Fakat 1399'da Memlûk sultanlığı tahtındaki değişiklikten istifade eden I. Bayezid, Firat üzerinden Memlûk nüfuz sahasına indi. Elbistan, Malatya, Darende, Divriği'yi idaresi altına aldı. Osmanlı sultanının bu fetihleri Mutahharten'in endişelerini iyice artırdı. Çünkü Anadolu'da Türk birliğini sağlamayı amaçlayan bu fetihlerden sonra sıranın kendisine geldiğini iyice görüyordu. Bayındırlı Yülük Osman Bey ise Misır Memlûk sultanından istediğini elde edemediğinden dolayı Kara Erzincan Emiri Mutahharten ile birlikte Avnik'te ikamet etmekte olan Timur'a $^{5}$ katıldı (Tihranî 1993: 47; Nizamüddin Şami 1987: 153). Böylece Mutahharten'in aracıllğı ile kurulan Timur-Akkoyunlu ittifakı

4 Sivas hükümdarı Kadı Burhan ed-Dîn 1396'da Kara Yülük Osman Bey tarafından öldürülmüştür (Konukçu, 1998: 38; Uzunçarş111 1968: 220-221).

5 Bilindiği gibi, Emir Timur Anadolu harekâtı sırasında Erzurum bölgesine geldiği zaman Erzincan Emiri Mutahharten'e elçi göndererek onu, kendisine itaat etmeye davet etti. O da çeşitli hediyelerle Timur'un katına gelerek itaatini arz etti (Nizamüddin Şami 1987: 103). 
TÜBAR-XXXV / 2014-Bahar / Akkoyunlular ve Erzincan

kuruldu. Bu ittifak sonucunda Kara Yülük Osman Bey 1400 yılı Temmuz ayında Anadolu üzerine yürüyen Timur'a bütün ailesi ile katılacak, Sivas'in ele geçirilmesinden sonra güneyde başlayan harekâtta bizzat rol oynadıktan sonra Ankara Savaşında da Osmanlı sultanı I. Bayezid'e karşı Timur'un yanında savaşacaktır (Yücel 1991: 290).

$\mathrm{Bu}$ arada bölgeyi etkileyen en büyük olay vuku buldu ki, bu da Erzincan emiri Mutahharten 1403 yılı sonlarında hayatını kaybetmesiydi. Çünkü ondan sonra Erzincan tahtına kimin geçtiği malûm değildir. Ancak İspanya'dan sefaret heyeti ile Semerkand'a giden İspanyol Ruj Gonzales de Clavijo, Erzincan'a ulaştığı zaman Erzincan tahtında Şeyh Ali isminde bir emirin Timur adına bölgeyi idare ettiğinden bahsetmektedir (Konukçu 1994: 797).

Erzincan bölgesinde bu işler olurken 1403 yılında Kara Yülük Osman Bey de ağabeylerine bağlı diğer Akkoyunlu cemaatini idaresi altında topladı. Meydana getirdiği ve her zaman yegâne dayanak olan "ulus" sayesinde kısa bir süre sonra Doğu Anadolu, Azerbaycan, Batı ve Orta İran ile bugünkü Irak ve Suriye'nin kuzey kesimlerini içine alan sahada "sahipkıranlık davası güden büyük bir imparatorluk" haline gelecek olan devleti tesis etti (Cöhçe 1997: 126).

Erzincan'da ise emir Şeyh Ali'den sonra Şeyh Hasan tahta geçti. Karakoyunlu hükümdarı, Azerbaycan'1 koruması için oğlu Şah Mehmed'i Tebriz yakınındaki Ucan yaylağında bıraktıktan sonra Erzincan üzerine hareket etti. Şehri elinde tutan Şeyh Hasan, savunma tedbirleri uygulayarak Türkmen ordusunu karşıladı. 40 gün devam eden kuşatmadan sonra Şeyh Hasan, yanına aldığı şehrin eşraf ve ayanıyla Kara Yusuf'un huzuruna çıkarak şehrin anahtarlarını sundu. Bunun üzerine Karakoyunlu hükümdarı Erzincan'1 Pîr Ömer'in yönetimine bıraktı. O, burada bulunduğu sırada Sultan Ahmed-i Celayir ordusu ile Tebriz üzerine hareket ederek Şah Mehmed'i mağlup etti. Bunun üzerine Kara Yusuf, Erzincan'dan tekrar Tebriz'e geri döndü (1410) (Hasan Rumlu 1931: 80). Pîr Ömer, Erzincan'a yerleşerek bağımsız bir emir gibi hareket etmeye başladığı gibi ardından da Karasu/Fırat kıyısındaki Kemah'1 ele geçirmek için hazırlıklar yapmaya başladı. Ancak Kara Yusuf ikinci defa Erzincan bölgesi üzerine hareket ederek Bayburt, Tercan ve İspir'i ele geçirerek Erzincan'a katarak Pîr Ömer'in hâkimiyetine bıraktı (1409) (Tihranî 1993: 67-68; Hasan Rumlu 1931: 78).

Pîr Ömer'in hâkimiyet ve kudretinin artması üzerine daha önce ele geçirmek için hazırlık yaptığı Kemah üzerine hareket ederek Kemah kalesini kuşatma altına aldı. Kemah bölgesini hâkimiyetinde tutan 
Bayındırlı başbuğlarından Yakup Bey, kalede İnak Hasan'1 bırakarak Pîr Ömer ile savaşmak üzere dişarıya çıktı. İki taraf arasında vuku bulan savaşta Yakup Bey mağlup olarak yakalandı. Pîr Ömer, onu kale halkına göstererek kalenin teslimini istedi ise de İnak Hasan teslim olmayı reddetti. Bunun üzerine Pîr Ömer, Yakup Bey'i Kara Yusuf'a gönderdikten sonra Kemah'1 ele geçiremeden Erzincan'a döndü. Bu olay üzerine Pîr Ömer, Kara Yülük Osman Bey'in kendi üzerine geleceğinden korktuğu için Karakoyunlu Başbuğundan yardım istedi. Bunun üzerine Kara Yusuf, Emîr-î Dîvân Bayram Bey, Baba Hacı Bey, Bayazid-i Ayinlu ve Emîr İlyas-1 Hacılu'yu yirmi bin kişilik süvari ile yardıma gönderdi. $\mathrm{Bu}$ emirler, kışlamak için Mardin havalisine giderken Aladağ' ${ }^{6}$ varıp orada konakladılar. Pîr Ömer ise onlarla birlikte olabilmek için Erzincan'dan Aladağ'a hareket etti. Tercan bölgesinde Höbek $^{7}$ mevkiine geldiğinde Akkoyunlu başbuğu Kara Yülük Osman Bey de Mihirî-fer yaylağında bulunuyordu. Kara Yülük Osman Bey'in yeğeni Pilten $\mathrm{Bey}^{8}$ kendisine Pîr Ömer'in Hubik mevkiine geldiği haberini verdi. Bunun üzerine o, Pîr Ömer'in üzerine hareket etti (Tihranî 1993: 69-70; Hasan Rumlu 1931: 120-121).

Akkoyunlu kaynağına göre yiğitlik ve cesaret bakımından ünlülerin önde gelenlerinden birisi olan Pîr Ömer, Osman Bey'in üzerine geldiğini haber alınca ordusunu düzene sokarak harekete geçti. İki taraf arasında yapılan savaşta Pîr Ömer mağlup ve esir edildi. Osman Bey, Pîr Ömer'i yanına alarak Erzincan önlerine geldi. Şehrin teslim edilmesi için onu görevlendirdi. Fakat Pîr Ömer verdiği cevapta; "şehir başkasınındır" diyerek Erzincan'ın teslimi hususunda direndi. Bunun üzerine Osman Bey, Pîr Ömer'in öldürülmesini emretti ise de Ali Bey, Şems ed-Dîn Mirza ve İskender Mirza, Yakup Bey'in Kara Yusuf'un elinde esir olduğunu hatırlatarak Karakoyunlu emirinin öldürülmemesini istediler. Erzincan'ın ele geçirilmesi gerçekleşmeyince Akkoyunlu başbuğu Kemah üzerine hareket etti. Burada Pîr Ömer, Kara Yülük Osman Bey'in elinden kaçtı ise de yakalanarak öldürüldü (Tihranî 1993: 69-70; Hasan Rumlu 1931: 121-122; Andreasyan 1975: 104; Woods 1993: 88). Pîr Ömer'in öldürülmesi haberi bu sırada Sehend yaylağında bulunan Kara Yusuf'a ulaştı. Bunun üzerine o, Akkoyunlu hükümdarına karşı savaşmaya hazırlandığı bir sırada Timurlu Şahruh'un Azerbaycan

6 Van Gölü'nün kuzeyinde bulunmaktadır. Karakoyunluların yaylak merkezlerinden birisidir. Ağrı Dağı da Ala Dağ olarak zikredilmektedir.

7 Kiğı'ya bağlı Hubik Köyü.

8 Pilten Bey bu sırada Kiğı'ya hâkim bulunuyordu. 
TÜBAR-XXXV / 2014-Bahar / Akkoyunlular ve Erzincan

taraflarına hareket etmesi sebebiyle bu hareketinden vazgeçti. Fakat oğlu Ebû Said'i Erzincan'1 ele geçirmesi için buraya gönderdi (Tihranî 1993: 71; Hasan Rumlu 1931: 122). Karakoyunlu başbuğunun oğlu Ebû Said Erzincan'1 ele geçirdi'ise de ancak burada fazla kalamadı. Çünkü babasının ölümünden sonra Erzincan halkı Ebû Said'e isyan ederek Emîr Mutahharten'in torunu Yar Ali'yi emirlik tahtına oturttular (Tihranî 1993: 76; Hasan Rumlu 1931: 123). Erzincanlllar her ne kadar Ebu Said'e isyan ettilerse de kaynaklar bu dönemde Karakoyunlu hükümdarı İskender'in hâkim olduğu bölgeler arasında Erzincan'inda bulunduğunu söylemektedirler (1428) (Andreasyan 1975: 109).

Akkoyunlu hükümdarı Kara Yülük Osman Bey, Karakoyunlularla yaptığı Şeyh Kendi Savaşından sonra Timurlu hükümdarı Şahruh ile İskender Mirza arasında yapılan Eleşkird Meydan Muharebesi'ne Timurluların yanında katıldı. Bu savaşta, Karakoyunluların mağlup olmaları üzerine Osman Bey önce Mardin bölgesini akınlara uğrattıktan sonra Erzincan'a geldi. Burayı kuşattığı sırada Trabzon hükümdarı Akkoyunlu ordugâhına gelerek Erzincan kuşatmasına yardımcı olduğu gibi Kemah'ta bulunan Yakup Bey de gelerek babasının hizmetine girdi. Bunun üzerine Kara Yülük Osman Bey, hâkim bulunduğu bölgelerden Şark-i Karahisar'1 onun emrine, Tercanat ${ }^{10}$ bölgesini de kardeşinin oğlu Musa Bey'e verdi. Akşehir, İnak Hasan'ın Bayburt Kutlu Bey'in hâkimiyetine bırakıldı (Tihranî 1993: 90; Hasan Rumlu 1931: 146-147; Hinz 1992: 28; Yücel 1986: 291). Kara Yülük Osman Bey, her birini alıp akrabalarına bıraktığı bu fetihlerin genel eğilimine bakıldığı zaman konfederasyon içindeki belli başlı güç odakları arasında bir denge kurma isteğini açıkça yansıtmaktadır (Woods 1993: 91; Sanjian 1969: 176). Böylece Erzincan çevresi tamamen Akkoyunluların eline geçti.

Esasen Erzincan valisi Yar Ali, Akkoyunlu kuşatması karşısında, Karakoyunlu hükümdarı İskender Mirza'yı Erzincan'a davet ederek, şehri kendisine vermeyi taahhüt etti. İskender Bey, Erzincan önlerine kadar geldi ise de Yar Ali sözünü tutmayarak şehri Karakoyunlu başbuğuna teslim etmedi. Bunun üzerine İskender Bey, Azerbaycan taraflarına

9 Karakoyunlu hükümdarı Kara Yusuf öldüğü zaman Ebû Said Erzincan'da bulunuyordu. (Hasan Rumlu 1931: 122).

10 Bu kelimenin, Yukarı ve Aşağı Tercan şekline de rastlamak mümkündür. Tercan-1 Ulya, Tercan-1 Süfla diğer karşılıkları olmaktadır. Bu isimler Karasu- Tuzla çayına göre ele alınmalıdır. Kitab-1 Diyarbekriyye'de iki Tercan'a karşılık olarak Tercanat kelimesi kullanılmıştır (Konukçu 1998: 29); Kahraman, "at" takısını Arapça "lar-ler" anlamında kabul etmektedir (Kahraman 2009: 506). 
hareket etti (Tihranî 1993: 90). Osman Bey, onun arkasından gitti ise de geriye dönerek Erzincan'ı tekrar kuşatma altına aldı. Kışın gelmesine bakmaksızın kuşatmayı devam ettiren Kara Yülük Osman Bey sonunda burayı ele geçirdi (Tihranî 1993: 92). Bunu Çemişkezek'in ele geçirilmesi takip etti ve yönetimini yeğeni Nur Ali Bey'e bıraktı. Kendisi de Urum Saray $^{11}$ yaylağına gitti (Tihranî 1993: 94). Bu sırada Besni ve diğer Memlûk kaleleri üzerine yapılan Türkmen akınları ve Akkoyunluların Harput ile Erzincan'ın kuşatmasının yarattı̆̆ Memlûk-Akkoyunlu sınır gerginlikleri Memlûk hükümdarı Barsbay'ı 1429'da Harput'u kurtarmak üzere bir öncü kuvveti göndermeye itti. Fakat Memlûk kuvvetleri Şam'da toplandıkları bir sırada Akkoyunlu hükümdarı Kara Yülük Osman Bey, Erzincan'1 ele geçirdi (Woods 1993: 92).

1435 baharında Timurlu hükümdarı Şahruh Azerbaycan sınırına ulaştığı zaman Karakoyunlu hükümdarı İskender bölgeyi terk ederek Aras vadisi üzerinden batıya kaçtı. Şahruh, İskender'in kaçışını derhal Kara Yülük Osman'a bildirerek Osmanlı topraklarına sığınmadan önce durdurmasını emretti ${ }^{12}$. Akkoyunlu hükümdarı, Karakoyunlu başbuğu İskender'i Erzurum önlerinde durdurmaya çalıştı ve nihayet aralarında husumet bulunan iki Türkmen hükümdarı Erzurum önlerinde savaşa tutuştular. Yapılan savaşta Kara Yülük Osman Bey aldığ 1 yaralar üzerine Erzurum'da vefat etti (1435) (Hasan Rumlu 1931: 215; Andreasyan 1975: 112; Konukçu 1998: 38) ${ }^{13}$. O ölmeden önce gerçekleştirdiği fetihlerini oğulları arasında paylaştırdı. Silvan ve Tercil Bayezid'e verildi (1424), Harput ise Ali Bey'e bırakıldı (1429). Yakup Bey, Kemah'tan başka Erzincan'a da hâkim oldu ise de Erzincan daha sonra (1432) Hamza'ya verildi. Erzurum ise (1433) Şeyh Hasan'in payına düştü (Woods 1993: 95).

Akkoyunlu başbuğunun ölümü üzerine yeğenleri (Ahmed Bey’i oğulları) Kılıç Arslan, Kutlu ve Hüseyin beyler, Bayındırlıların başına geçebilmek için harekete geçti iseler de Ulus bunlara fazla itimat etmedi. Bunun üzerine Kutlu Bey kendi vilayeti Bayburt'a, Kılıç Arslan Bey ise Palu'ya gitti (Tihranî 1993: 114). Gerçekten de Osman Bey'in ölümünden sonra (Kara Yülük Osman Bey'in ağabeyi Ahmed Bey'in

11 Erzincan yakınlarında şimdi Mecidiye köyü.

$12 \mathrm{Bu}$ savaşta Akkoyunlu askerlerinin çoğu kışlaklarda bulunduğu için Akkoyunlu ordusu, Karakoyunlu ordusundan sayıca daha azdı (Woods 1993: 95).

13 Savaşta ağır yaralanan Osman Bey'i oğlu Şeyh Hasan Erzurum'a götürdü. Diğer oğlu Bayezid ile damadı Ahmed Bey Purnak da yapılan savaşta ölenler arasında bulunuyordu. (Woods 1993: 95) 
TÜBAR-XXXV / 2014-Bahar / Akkoyunlular ve Erzincan

oğlu) Kılıç Arslan Erzurum'u ele geçirmek üzere harekete geçti. Fakat buna muvaffak olamayarak Palu'ya çekilmek zorunda kaldı (Woods 1993: 124).

Akkoyunlu hükümdarı Osman Bey'in vefatı üzerine Ali Bey, Muhammed Bey ve Mahmud Bey savaş alanında Akkoyunlu askerleri ile birlikte Ulus'a hareket ettiler. Onlar Ulus'a varmadan önce Cihângir Mirza, Ali Bey'in askerleri ile birlikte Tercan mevkiinde Ali Bey'e ulaştı (Tihranî 1993: 115). Bunun üzerine Ali Bey, büyük bir şevket ve ihtişam ile Ulusa vardı. Fakat Ali Bey, babasının başına gelenlerden habersizdi ve Ulus' $a$ vardığı zaman onun ölüm haber yayıldı. Sonra bütün Ulus toplanarak ona itaat etti ${ }^{14}$ ve onun emirliği konusunda birbirleriyle anlaşmaya ve ittifaka vardılar. 1435'de Diyarbekir'de yazılan bir Ermeni kaynağında Osman Bey'in oğlu Ali Bey'in, ulu babası tarafından daha önce veliaht ilan edildiği kaydı yer almaktadır (Andreasyan 1975: 112). İşte bundan dolayı Akkoyunlu yöneticileri ona itaat edip boyun eğdiler. Ardından da Ali Bey, oğlu Cihângir Mirza'yı Ulus'ta vekil bırakarak Cuki Mirza'nın yanına gitti ve Erzincan'da ona ulaştı (Tihranî 1993: 115116;Hasan Rumlu 1931: 215-216). Gerçekten de Ali Bey, hem Şahruh'tan hem de Memlûklulardan emirlik beratı ve hil'atı alarak 1435 'de Akkoyunluların başına geçtiyse de aşağıda görüleceği gibi Mardin valisi olan kardeşi Hamza Bey'in baskılarına maruz kalacaktır (Cöhçe 1997: 126). Timurlu hükümdarı Şahruh, belki de Akkoyunlular içinde belirecek olan mücadeleyi gördügünden dolayı Erzincan'da Akkoyunlu başbuğlarının katıldığı ikinci bir kurultay topladı. Bu kurultaya katılan Ali Bey, Şeyh Hasan, Yakup Bey, Yakup Bey'in oğlu Cafer ve Pîr Ali Bey'in hanesinden Nur Ali'nin huzurunda Ali Bey ikinci kez Akkoyunluların hükümdarı seçildi. Ayrıca bu kurultayda Cuki Mirza, burada Yakup Bey'e Erzincan'1 ikta olarak verdi (Hasan Rumlu 1931: 217; Woods 1993: 126). O da şehrin yönetimine oğlu Cafer Bey'i tayin etti (Tihranî 1993: 119).

$\mathrm{Bu}$ arada Timurlu hükümdarı Şahruh'un korkusuyla Osmanlı sınırına kadar giden Karakoyunlu hükümdarı İskender Mirza, onun geri

14 Woods, Muhammed, Mahmud, Ali Bey ve Ali Bey'in oğlu Cihângir Tercan yakınlarında gayr-1 resmi bir kurultay toplayarak Kara Yülük Osman Bey'in oğlu Ali Bey'i yerine veliaht gösterdiğini ifade ederek Akkoyunlu hükümdarı olarak Ali Bey'i tanıdıklarını, ancak Mardin bölgesini elinde bulunduran Hamza ile Erzincan ve Kemah bölgesini elinde bulunduran böylelikle de geniş yaylaklara hükmeden Yakup ve oğlu Cafer gibi güçlü Akkoyunlu beylerinin toplantıya katılmadıklarını belirtmektedir (Woods 1993: 124-126). 
döndüğünün haberini alınca Osmanlı hududundan çekilerek Saruçiçek ${ }^{15}$ yaylağına geldi. Onun Saruçiçek yaylağına geldiğini haber alan Ali Bey, savaşmak niyetiyle asker toplayıp İskender'in üzerine hareket etti. Bayındırlıların büyük emirleri Yakup Bey, Pilten Bey ve Şeyh Hasan Bey, Harput düzünde Ali Bey'e katıldılar (Tihranî 1993: 125). Bütün emirlerin birleşmesi üzerine, İskender Mirza'nın nasıl karşılanacağ üzerinde savaş meclisi topland ${ }^{16}$. Toplantıda Ali Bey'in Harput yolundan gidilmesi teklifine karşıllık, emirler Erzincan yolunu tavsiye edince bu görüş kabul edilerek Erzincan üzerine hareket edildi. $\mathrm{Bu}$ sırada Erzincan'ın yönetimi yukarıda da söylediğimiz gibi Yakup Bey'in büyük oğlu Cafer Bey'in elinde idi ve o da Ali Bey'e karşı gelmişti. Cafer Bey'e haber göndererek emirliğin kendisine verileceğini bildirmeleri üzerine o da, Akkoyunlu başbuğlarının yanına varmak için hareket etti. Fakat yolda yakalandi. Ali Bey, Yakup Bey, Muhammed Bey ve Şeyh Hasan Bey’i bir ordu ile birlikte Erzincan'1 kuşatmaya gönderirken kendisi de mutad yaylak için Bayburt taraflarına gitti (Tihranî 1993: 126-127). Birkaç gün sonra Cafer Bey'in askerleri hisardan çıarak Yakup Bey ile savaştılarsa da yenilmekten kurtulamadılar. Şehir halk1 durumun kötüleşeceği endişesiyle kale kapılarını açarak şehri Yakup Bey'e teslim etti. Ahmed Bey'in oğlu Kutlu Bey, şehrin dinî önderi ulemadan Hace Mahmûd-i Erzincanî ile birlikte kendisine ait olan Bayburt kalesine çekildi (Tihranî 1993: 127).

$\mathrm{Bu}$ arada İskender Mirza Akkoyunlu başbuğlarının arasında var olan anlaşmazlıklardan fazlasıyla yararlanma yoluna gitti. Saruçiçek yaylağından Malatya'ya geldiği sırada eski dostluklarına dayanarak Akkoyunlu Ahmed Bey'in oğlu Kılıç Arslan Bey'i yanına çağırdı. Kılıç Arslan Bey, kardeşleri ile birlikte İskender Mirza'ya katıldı. Böylece Karakoyunlu hükümdarı Kılıç Arslan Bey'in yardımı ile Fırat Nehri'ni geçerek Harput havalisinde konakladi. Harput valisi Pehlivan Seydi Ali, İskender Mirza'nın ordusuna saldırarak birçoklarını öldürerek başlarını kesti ve kesilen başları Ali Bey'e gönderdi (Hasan Rumlu 1931: 225). Ali Bey, bir kez daha savaş divanını topladıysa da bu kez Yakup Bey, kardeşi Ali Bey'e verdiği desteği çekti. İskender Mirza ise Akkoyunlu hükümdarı Ali Bey'in asker toplayarak üzerine geldiğinin haberini alınca da Kiğı taraflarına giderek buraları istila etti. Ardından da Erzincan ve Tercan bölgesine inerek yağmasını sürdürdü (Hasan Rumlu 1931: 225). Esasen

15 Saruçiçek yaylası, Arapkir'in kuzeybatısında, Divriği'nin güneydoğusundadır.

16 Toplantıya Akkoyunluların hükümdarı olarak Ali Bey ile birlikte Yakup Bey, Şey Hasan, Mahmud, Muhammed ve Pilten Bey katılmıştır (Woods 1993: 128). 
TÜBAR-XXXV / 2014-Bahar / Akkoyunlular ve Erzincan

İskender Mirza, bu sırada ailesini Çadırkaya/Pekeriç kalesine bıraktıktan sonra tekrar Erzincan havalisine gelerek burayı yağmaladıktan sonra Erzurum taraflarına gitti (Tihranî 1993: 127-128) ${ }^{17}$. Fakat Ali Bey, mevsimin kış olması dolayısıyla onun üzerine asker sevk edemediğinden dolayı kışlamak için Diyarbekir'e gitti (Tihranî 1993: 128).

$\mathrm{Bu}$ arada Ali Bey, oğulları Hüseyin ile Cihângir'in Memlûk hükümdarı Barsbay'ın elinde esir bulunmalarından dolayı bu hükümdarla görüşmeye oturdu. $\mathrm{O}$, bu yolla oğulları Hüseyin ile Cihângir' in serbest kalmasını ve güney sınırlarının güvenliğini sağlamayı umuyordu. Memlûk sultanı ise Harput'un kendisine bırakılması karşılığında oğullarını serbest bırakacağını ve Diyarbekir üzerindeki yönetimini tanıyacağını kabul etti. Bu sırada Erzincan yöresini hâkimiyetinde bulunduran kardeşi Yakup Bey'in, Mardin yörelerine hâkim olan diğer kardeşi Hamza'nın ve Erzurum'da da Karakoyunlu hükümdarı İskender'in büyüyen muhalefetiyle karşılaşan Ali Bey'in bu teklife boyun eğmekten başka çaresi yoktu. Bunun üzerine Ali Bey, Harput'u Memlûkların müttefiki olan Dulkadirlilere (Zü'l-kadr) bıraktı (Woods 1993: 129). Barsbay'ın serbest biraktığı Hüseyin ile Cihângir Mirza Harput'un tesliminden sonra Ali Bey ile birleşmek üzere Erzincan'a geldiler (Tihranî 1993: 135). Bundan sonra Uzun Hasan Bey ${ }^{18}$ 'de Erzincan'a geldi. Böylece Akkoyunlu hükümdarı Ali Bey'in üç oğlu Cihângir Mirza, Hüseyin Bey ve Uzun Hasan Erzincan'da buluşarak amcaları Yakup Bey ile görüştüler (Tihranî 1993: 136).

Bu sırada Ali Bey'in kardeşi Hamza 1437 yılı yazının başında Karakoyunluların Bağdad valisi olan İsfahan Bey'i (Kara Yusuf'un diğer oğlu) mağlup ettiği için büyük bir ün kazandı. Bundan sonra Mardin yakınlarında İzz ed-din Hacılu, Musullu, Purnak, Koca Hacılu, Döğer gibi boylarla Hisn-1 Keyfa (Hasan Keyf) Eyyubilerini kendine bağladıktan sonra bunlardan oluşturduğu ordusu ile Karakoyunluları bölgeden uzaklaştırdı. Ardından da Diyarbekir üzerine yürüyerek burayı ele geçirdi. Şehrin valiliğini yapan Uzun Hasan kaçarak Erzincan'da bulunan babasının yanına geldi (Woods 1993: 129-130). Fakat Ali Bey,

17 İskender Mirza'nın faaliyetlerinden bahseden başka bir kaynakta ise İskender Mirza'nın Erzurum'a gitmeyip Akkoyunlular karşısında Erzincan'a kapandığı bilgisi mevcuttur (Andreasyan 1975: 115)

18 Fars Kaynaklarında ise Hasan-1 Dıraz olarak geçen Uzun Hasan, Akkoyunluların en büyük hükümdarı idi. 1423'de Diyarbekir'de dünyaya geldi. Ali Bey'in oğludur. Annesi Saray Hatun'dur. Bir süre amcası Hamza Bey'in yanında kaldı. 1441'de babasını kaybetti. 1453'de hükümdarlığını ilan etti. 1469'da da Azerbaycan'1 ele geçirmiştir (Konukçu 1998: 41-42) 
belki de kendisinin en büyük destekçisi olan abisi Yakup Bey ile umduğu gibi yakınlaşamadığ 1 için oğlu Üveys ve birkaç akrabasıyla birlikte Osmanlı hükümdarı II. Murad'a sığındı (Tihranî 1993: 140).

Ali Bey'in oğlu Cihângir Mirza, Diyarbekir'in amcası Hamza'nın eline geçmesi üzerine Memlûkluların yardımını sağlamak üzere Sultan Eşref'in yanına gitti. Bunun üzerine elli bin kişilik bir süvari ordusunu Emir-i Leşker Tanrı Vermiş ve Mısır emir-i kebiri ve Şam ve Halep naibi Korkmaz gibi emirlerin komutasında Diyarbekir'e gönderdi. Cihângir Mirza, bu ordu ile Erzincan üzerine varınca şehir teslim oldu ve Yakup Bey, harekete geçerek "şehir senindir" diyerek birlikte Erzincan'a girdiler. Bu arada Sultan Hamza'nın Erzincan üzerine hareket ettiği haberi ulaştı (Tihranî 1993: 142-143). Ancak Memlûk ordusu Sultan Hamza'nın üzerine varamadan sultan Eşref'in (Barsbayı) öldü. Bunun üzerine ordu Suriye'ye dönmek zorunda kaldı. Bu arada Memlûk ordusunun korkusundan kaçan Yakup Bey'in oğlu Cafer Bey, ordunun dönüş haberini işitince Erzincan'a yöneldi. Erzincan ovas1 ile Vaskirt'ten ${ }^{19}$ kuzeye uzanan yoldaki Urum Saray'a geldiği zaman Sultan Hamza'nın da Erzincan'a geldiği haberi ulaştı. Ali Bey'in üç oğlu Cihângir Mirza, Hüseyin bey ve Uzun Hasan şehir sakinlerini teselli ederek ihtiyaçlarını gidermeye çalıştılar (Tihranî 1993: 143).

Uzun Hasan, kardeşleri Hüseyin Bey ve Cihângir Mirza ile birlikte Erzincan'da bulunduğu bir sirada Sultan Hamza da Erzincan üzerine hareket etti. Bu arada Cihângir Mirza, bu sirada Urum Saray'da bulunan Cafer Bey'e elçi göndererek onu şehre davet etti. Sultan Hamza, Erzincan üzerine hareket ederek şehrin yakınlarına geldi. Şehrin durumunu öğrenmek için birkaç bahadır ile birlikte Bahtiyar Ağa ileriye gönderildi. Ayrıca Pîr Muhammed-i Pörnak ile Buze oğlu Ahmed'te Sultan Hamza'nın yanında öncü olarak bulunuyorlardı. Bahtiyar Ağa, Erzincan'a doğru yol aldığı bir sırada yaptığı savaşı kaybetti. Bu sırada Uzun Hasan Bey, emrindeki Akkoyunlu askerleri ile Sultan Hamza'nın öncülerine saldırdı. Yapılan savaşta Sultan Hamza'nın öncülerinin birçoğu öldürüldü ve Buze oğlu Ahmed atından düşürülerek yakalandı. $\mathrm{Bu}$ galibiyet üzerine Erzincan'da bulunan Cihângir Mirza ile Cafer Bey direnmeye başladılarsa da askerlerinin birçoğu Sultan Hamza'nın korkusundan Kemah kalesine kaçtılar. Bundan sonra Sultan Hamza Erzincan önlerine gelerek şehri kuşatma altına aldı. Ancak Sultan Hamza'nın Akkoyunlu başbuğlarından ziyade Mamaşlu kabilesine önem vermesi üzerine Bayındırlıların ileri gelenleri Cihângir Mirza'nın yanına 
TÜBAR-XXXV / 2014-Bahar / Akkoyunlular ve Erzincan

geçmeleri üzerine, Erzincan'1 savunan Akkoyunlu ordusu amcaları Hamza'yı yenmeyi başardılar ve Hamza bozguna uğrayarak Diyarbekir'e çekildi (Tihranî 1993: 147-149). Ailesi ile hazinesi Uzun Hasan'ın eline geçti. Bundan sonra Cafer Bey, bayındırlıların liderlik koltuğuna oturdu (Tihranî 1993: 149; Hasan Rumlu 1931: 233).

Ancak Cafer Bey'in hoş karşılanmayan bazı hareketlerinden dolayı Bayındırlılar ondan incinerek sultan Hamza'nın tarafina geçmeye başladılar. Bu arada babası Yakup Bey de oğluna destek vermeyi reddederek Kemah kalesine kapandı. Sultan Hamza'ya sı ğınmayan Bayındırlılardan bir kısmı Yakup Bey'in yanına sığınmaya başladılar. Bunun yanı sıra Ali Bey'in de Osmanlıların yanından dönüşü Cafer Bey'in liderliğini zora sokan olayların başında gelmektedir (Woods 1993: 133).

Sultan Hamza'ya katılan ancak ulusla birlikte kalan Hoşkadem Bey, Kuş Bey ve Koca Hacı oğlu Mihmad Bey, Cafer Bey'e haber göndererek onu tekrar İl'e getirdiler. Cafer Bey'in Ulus'a gelmesi üzerine Kemah'a gitti. Ali Bey de bu sırada geriye dönmüş ve geçim sıkıntısı içinde bulunuyordu. Kiğı'ya hâkim olan Pîr Ali Bey'in oğlu Pilten Bey, onu yanına davet ederek yardım edeceğini bildirdi. Bu davete inanan Ali Bey Kiğı'ya gitti. Ancak o, Ali Bey'e iki kızının da kendi oğulları ile evlenmelerine müsaade etmesini söyledi. Eğer müsaade etmez ise zorla alacağını da ilave etti. Ali Bey, onun isteğini geri çevirmekten aciz olduğu için çaresiz evlilik işine rıza gösterdi (Tihranî 1993: 150-151).

Ulus'a gelen Cafer Bey, tekrar kötü işlere girdi. Onun bu davranışlarını gören Ulus, tekrar yüz çevirerek Kemah'ta bulunan Yakup Bey'in etrafında toplanmaya başladılar. Ali Bey'de bu sırada kardeşi ile birleşince Bayındırlılar, dağınık bir durumdan kurtularak tekrar büyük bir topluluk olamaya başladılar (Tihranî 1993: 151). Bu sırada Bayındırlılar, Sultan Hamza, Ali Bey, Hüseyin Bey ve Cihângir Mirza'nın hâkimiyetinde bulunuyorlardı. Uzun Hasan Bey ise amcası Yakup Bey'in hizmetinde idi (Tihranî 1993: 152). Bir müddet Erzincan bölgesinden uzaklaşan sultan Hamza, tekrar Yakup Bey'in hâkimiyetinde bulunan bölge üzerine yönelerek Kemah ve Şark-i Karahisar bölgesine geldi. Bu durumdan çekinen Yakup Bey, Cihângir Mirza'ya kaleyi kendisine teslim edeceğine dair haber gönderdi ise de Sultan Hamza ona, kaleyi teslim etmemesini çünkü kendisine bir zarar vermeyeceğini bildirdi. Bu arada Uzun Hasan Bey'in babası Ali Bey, Halep civarı kasabalarından biri olan 
Şayzar' $\mathrm{da}^{20}$ hayatını kaybetti $(1443)^{21}$. Onun ölümünden az sonra sultan Hamza tekrar Erzincan üzerine hareket ederek şehri kuşattı. Durumun kötüleştiğini gören halk, şehri teslim etti (Tihranî 1993: 168; Hasan Rumlu 1931: 243). Böylece Akkoyunlu yaylaklarından en önemlisi olan Erzincan ele geçirilmesi, ona sultan unvanını alarak Bayındırlıların en büyük lideri haline gelmesi konusunda önemli bir katkı sağladı (Woods 1993: 135). O, Erzincan'1 ele geçirdikten sonra burayı kardeşi Şeyh Hasan'a ikta olarak verdi. Fakat bir müddet sonra sultan Hamza Erzincan'da hastalandı. Bunun üzerine tekrar Mardin yöresine geriye dönmek üzere (Hasan Rumlu 1931: 241) Diyarbekir'e gittiği sırada öldü (1444) (Tihranî 1993: 168)22. Ancak onun bu liderliği fazla uzun sürmedi. Akkoyunlulardan ilk sikkeyi kestiren Hamza Bey'dir (Cöhçe 1997: 126). Tihrani, sultan Hamza'nın ölümünden sonra Bayındırlıların mutlak hâkiminin Ali Bey'in oğlu Cihângir Mirza olduğunu ayrıca sultan Hamza'nın kızı Şah Sultan Hanım ile de evlendiğini belirtmektedir (Tihranî 1993: 169-170).

Sultan Hamza öldüğü sırada Erzincan, onun adına kardeşi Şeyh Hasan tarafindan idare ediliyordu (Hasan Rumlu 1931: 244). Sultanın ölümünden sonra Bayındırlılar iki başbuğun etrafında toplanmaya başladılar. Bunlardan birisi Cihângir Mirza, diğeri ise Şeyh Hasan Bey idiyse de iktidar Cihângir (1444-1453) Mirza'nın elindi bulunuyordu. Cihângir zamanında da iç çekişmeler devam etmiş ve Akkoyunlu emirlerinin bir kısmı Cihângir Mirza'dan ayrılarak Şeyh Hasan'a katılmışlard ${ }^{23}$. Kardeşi Uzun Hasan'ın bütün gayretlerine rağmen olaylar durmamıştır. Bu olaylar olurken Yakup Bey, Diyarbekir'e Cihângir Mirza'nın yanına gittiği bir sırada burada öldü (Tihranî 1993: 169-171). Onun ölümünden sonra Kemah, komutanlarından Celâl tarafindan idare edilmeye başlandı. Celâl, Şeyh Hasan'a haber göndererek kaleyi kendisine teslim etmek istediğini bildirdi. Esasen bu sirada Şeyh Hasan'da Kemah kalesini kuşatma altına almıştı. Şeyh Hasan kaleye geldiği bir sırada Celâl, onu yakalayarak hapsetti. Böylece Erzincan tahtı

20 Humus vilayetine bağlı meşhur kasaba.

21 Kardeşi Hamza Bey'in Akkoyunlu şehzadeleri tarafindan "Uluğ Bey” olarak tanınması üzerine Osmanlı sultanı II. Murad'a sığınmak zorunda kalan Ali Bey'e İskilip dirlik olarak verilmiştir (Cöhçe 1997: 126).

22 Ahsenü’t-Tevarih'te Sultan Hamza'nın ölüm tarihi 1440 olarak verilmektedir (Hasan Rumlu 1931: 243).

23 Şeyh Hasan'a katılan emirlerden en önemlisi Pilten Bey idi (Tihranî 1993: 171). 
TÜBAR-XXXV / 2014-Bahar / Akkoyunlular ve Erzincan

boş kaldı (Tihranî 1993: 169-172; Hasan Rumlu 1931: 244; Cöhçe 1997: 127).

Bunun üzerine Şeyh Hasan'ın komutanları bu sırada Bağdad'tan Birecik $^{24}$ bölgesine gelmiş bulunan Mahmud Bey'i (Kara Yülük Osman Bey'in oğlu) Erzincan'a davet ettiler. O, Birecik'i İbrahim'e bırakarak Erzincan'a doğru yola çıkararak buraya geldi (Tihranî 1993: 172; Hasan Rumlu 1931: 245). Uzun bir süre devam eden mücadelelerde Erzincan'1 ele geçirmeyi başardı (1446) (Woods 1993: 137). Bu dönemi anlatan başka bir kaynağa göre Kemah hâkiminin birkaç gün sonra Şeyh Hasan'1 serbest birakt1 ve o da Tercan bölgesine giderken Mahmud Bey tarafindan yakalanarak tekrar hapsedildi (Andreasyan 1975: 121-122). Bu sırada Cihângir Mirza'da Erzincan'ı kuşatmak için asker sevk etti (Hasan Rumlu 1931: 245; Andreasyan 1975: 122). Ancak Erzincan'1 amcasindan kurtarmakta başarısız oldu (Woods 1993: 137).

1447-1448 yılının sonlarında Karakoyunlu hükümdarlarından İskender'in oğlu Elvend Mirza, amcası Cihanşah Mirza'ya isyan etti. Erbil üzerine yürüyerek buraya ele geçirdi. Cihanşah, Karakoyunlu emirlerinden Rüstem-i Tarhan'ı onun üzerine gönderdi. Yapılan savaşta Elvend Mirza mağlup oldu ve Akkoyunlu Cihângir Mirza'nın yanına geldi. Karakoyunlu hükümdarı Cihanşah, Akkoyunlu emirinden Elvend'i istedi ise de o cevabında " $O$, bize sığınmıştır, onu teslim etmek yakışmaz" diyerek isteği reddetti. $\mathrm{Bu}$ durum üzerinden üç mevsim geçtikten sonra Cihanşah, Gence ve Berde'de kışladı. Ardından da baharın gelmesi üzerine Karakoyunlu ordusunu Emir Arapşah ile Kılıç Aslan'ın komutasında Erzincan'da bulunan Kara Yülük Osman Bey'in oğlu Mahmud'u üzerine gönderdi. Bu sırada Tercan havalisinde bulunan Musa Bey ile Şeyh Hasan'da onlarla birleşti. Böylece kuvvetli bir ordu haline gelen Karakoyunlular Erzincan'1 kuşatma altına aldılar. Bu arada Uzun Hasan, her ne kadar Mahmud Bey'e yardım edilmesi hususunda görüşlerini bildirdi ise de Akkoyunlu emirleri bu fikri benimsemediler. Kuşatmanın şiddetlenmesi, geçim kaynaklarının azalması üzerine şehri Cihanşah'a teslim ettiler (Tihranî 1993: 178-179; Hasan Rumlu 1931: 270). Cihanşah, Erzincan valiliğine Mahmud Bey'in yerine tekrar Şeyh Hasan'1 getirdi (Woods 1993: 139).Şehir ele geçirildikten sonra Erzincan halkından çoğu tutuklandı. Bundan sonra Cihanşah, Akkoyunlu Mirza İbrahim'i Cihângir Mirza'ya göndererek; "Ĕger Elvend Mirza'yı bana verirsen, esirleri serbest bırakırım, eğer vermezsen hepsini öldürürüm" dedi. Cihângir Mirza, gönderdiği cevabında, "Bize sığınmış olan bir

24 Urfa'nın Birecik ilçesi. 
kimseyi kendi iyiliğimizi düşünerek tehlikeye atmak doğru olmaz. Cihanşah, Erzincan'l anlaşmalar ve yeminlerle aldı̆̆ için insanlar bağlama veya serbest bırakma onun elindedir. İster bağışlasın isterse öldürsün kendisi bilir." dedi (Hasan Rumlu 1931: 271; Yinanç 1944: 176).

Bu cevap üzerine Cihanşah Mirza, Rüstem-i Tarhan'1 Diyarbekir taraflarına Akkoyunlular üzerine ve Bayezd-i Bistami'yi de Duharlu emirlerinin bazılarıyla birlikte Bayburd kalesini ele geçirmek için gönderdikten sonra kendisi de Tercan'a gitti (Tihranî 1993: 204). Güneyde yapılan Karakoyunlu- Akkoyunlu mücadelesinde Şeyh Hasan gibi Akkoyunlu emirleri Cihângir Mirza'ya karşı Karakoyunluların safinda yer alarak mücadele ettiler ki, Bu emirlerden Şeyh Hasan Ruha'da öldürüldü (Woods 1993: 141). O, burada bazı faaliyetlerde bulunduktan sonra Erzincan ile birlikte Tercan'1 Kılıç Aslan'a verdi. Kılıç Arslan'ın da damadı olan Musa'yı da ona nöker yaptı (Tihranî 1993: 204-205). Woods, Erzincan ile birlikte Tercan'ın da K1lıç Arslan'a verilmesini, Musa'yı da nöker olarak görevlendirmesini Ahmediler'le Pîr Alililer'in $^{25}$ Kara Yülük Osman Bey'in soyuna düşmanlıklarından yararlanmak istediği şeklinde yorumlamaktadır (Woods 1993: 141). Bu olaylar hakkında farklı kaynaklarda da bilgi vermektedirler. Bir Ermeni kaynağında; "1450 yılında Karakoyunlu hükümdarı (Tebriz sultanı) altmış bin kişilik askerle birlikte Erzincan üzerine hareket ederek burayı Bayındırlı Türkmenlerinin elinden aldı ve şehrin hâkimi ile kırk emiri esir ederek doğuya götürdü. Ardından Kemah kalesini ele geçirerek on bin kişiyi esir etti. Ayrıca İç Tercan, Yukarı Tercan (Tecanat), Bayburt, Kiğı, Koçak, Kelkit çayı havzası, Şiran, Sadak bölgelerini de hâkimiyeti altına aldı" kaydı bulunmaktadır (Andreasyan 1975: 123-125; Sanjian 1969: 217).

Akkoyunlular arasındaki bu iç çekişme biraz sonra yerini kuzeydeki yaylaklara hâkim olan oymaklar ile güneyde kışlakları ellerinde tutan gruplar arasındaki bir mücadeleye dönüştü. Bir türlü bu bölgeler arasındaki göç yolları tek bir siyasi otoritenin hâkimiyeti altına alınamadı. Bunu sağlamak için desteğine başvurulan Timurlular, Memlûklular, Osmanlılar ve hatta Karakoyunlular gibi diş güçlerin müdahaleleri de işleri büsbütün karıştırmaktaydı. Ağabeyi Cihângir'in Karakoyunlu Cihanşah'ın hâkimiyeti altına girmesinden memnun

25 Kılıç Arslan, Kara Yülük Osman Bey'den önceki Akkoyunlu hükümdarı Ahmed Bey'in oğlu idi. Musa Bey ise Ahmed Bey ile Kara Yülük Osman Bey'in kardeşleri olan Pir Ali Bey'in oğlu idi. 
TÜBAR-XXXV / 2014-Bahar / Akkoyunlular ve Erzincan

olamayarak harekete geçen Celâl ed-Din Ali Bey'in diğer oğlu Uzun Hasan olaylara müdahale etmeye başladı (Cöhçe 1997: 127).

Uzun Hasan Bey, Akkoyunlu emirleri arasında siyrilarak yanına aldığ 1 gerek Kara Yülük Osman Bey'in soyundan gelen gerekse Pîr Ali Bey'in soyundan gelen emirlerle birlikte Afşar, Emirlu, Bicanlu, Haydarlu, İvaz, Musullu, Purnak ve Koca Hacılu gibi kabilelerden aldığı askerlerden oluşan ordusu ile Karakoyunlulara karşı tek başına mücadeleye giriști (Woods 1993: 143). Fakat bu sirada amcası Kasım Bey, bu sirada elinde bulundurduğu Mazgirt ${ }^{26}$ kalesinden Erzincan üzerine yürüyerek burayı kuşattı. Durumdan haberi olan Uzun Hasan, Erzincan taraflarına hareket etti. Erzincan hâkimi Kılıç Arslan Bey ise Kasım Bey'in Erzincan'1 kuşatmaya geldiğini ve Uzun Hasan'ın da bu taraflara doğru hareket ettiğinin haberi alınınca bölgedeki hâkimiyetinin biteceği kuşkusuna düştü. Bu durum karşısında Şeyh Hasan, Musa Bey ve Mahmud Bey-i Kükeltaş'ın kendisi ile birlik olmalarını istedi. Ancak Uzun Hasan Bey, Kılıç Arslan'a haber göndererek, “amcamız Kasım Mirza, bizim düşmanımızdır. Bu diyarın fitne ve fesattan kurtulup emniyet ve güvenlik köşesine çekilerek istikrar bulması için senin görevin, onu kovmak konusunda bizimle anlaşmaktır" dedi. Bu haber Kılıç Arslan'a ulaşınca heyecanlanıp son derece mutlu oldu (Tihranî 1993: 222-223).

Kasım Mirza ise Uzun Hasan'ın harekete geçtiğini haber alınca, Erzincan kuşatmasını kaldırarak Şark-i Karahisar taraflarına yöneldi. Bu arada Sultan Hüseyin'de ona katıldı ve Urum Saray'a gittiler. Uzun Hasan Bey ise Erzincan önlerine gelerek burada karargâh kurdu. Kasım Mirza'nın buradan ayrıldığını görünce arkasından hücuma geçti. Kasım Mirza ise bu sırada ailesini Sirin'debırakıp Bayburt'u yağmalamaya gitti. Uzun Hasan Bey amcasının hanesini ve mallarını ele geçirdi. Ailesinin Uzun Hasan Bey'in eline geçtiğini duyan Kasım Mirza, askerlerinin de dağılması üzerine perişan bir duruma düştü. Uzun Hasan amcasının bu durumuna üzülerek ailesini ve mallarını geriye gönderdi (Tihranî 1993: 223-224).

Bundan sonra Uzun Hasan Bey, bütün gücü ile Kılıç Arslan üzerine hareket etti ve Kılıç Arslan'ın oğlunu askerleri ile birlikte yakalayarak kuşatma altındaki Erzincan'a getirdi (Tihranî 1993: 224). Uzun Hasan'ın hem amcası Kasım Mirza'ya hem de Ahmet Bey'in oğlu Kılıç Arslan'a karşı zafer kazanması onun güç kazanmasına neden oldu.

26 Tunceli'nin ilçesi. 
Uzun Hasan Bey, bundan sonra Erzincan'1 ele geçirmek için şehri kuşatmaya başladı. Bu sırada Kasım Mirza Şark- Karahisar'da, Kılıç Arslan ise Erzincan'da hazırlıklı bulunuyorlardı (Tihranî 1993: 225-226; Woods 1993: 143). Kılıç Arslan, durumun giderek kötüleştiğini görünce Karakoyunlu hükümdarı Cihânşah Mirza'ya haber göndererek Uzun Hasan Bey'in Erzincan'ı kuşatma altına aldığını haber vererek yardım istedi. Cihânşah ise Hüseyin-i Sa'dlu ile Emir Arabşah'ın komutasında on bin kişilik bir kuvvet gönderdi. Uzun Hasan kendi üzerine gelen Karakoyunlu ordusunu karşılamak üzerine hareket etti. Fakat bu sırada Kilıç Arslan, Karakoyunlu ordusunun başbuğlarına Uzun Hasan'ın üzerlerine geldiğinin haberini verdi. Bunun üzerine Karakoyunlu komutanları Urum Saray yolu ile Erzurum taraflarına hareket ettiler. Uzun Hasan ise arkalarından giderek Tercan bölgesini yağmaladı (Tihranî 1993: 227). Uzun Hasan Bey, Karakoyunlu hükümdarı Cihanşah'ın, Timurlularla savaşmak için doğuya doğru hareket ettiğini haber alınca da ordusu ile Azerbaycan taraflarına gitti. Az önce Erzincan'1 elinde bulunduran Kılıç Arslan'ın yardımına geldiğini söylediğimiz Emir Arabşah, bu firsattan yararlanarak tekrar Erzincan'a yönelerek burada yerleşti (Tihranî 1993: 228). Woods, Kilıç Arslan'ın Karakoyunlular tarafından sıkıştırıldığını ve hiçbir kurtuluş umudunun kalmadığını gören Kılıç Arslan'ın kenti terk ederek Uzun Hasan'ın yakın takibi altında Tebriz'e kaçtığını ve burada da Cihanşah tarafindan cezalandırıldığını ifade etmektedir (Woods 1993: 144).

$\mathrm{Bu}$ arada Kılıç Arslan'ın Erzincan'dan kaçışı Kasım Bey'e geri dönme firsatı doğurdu. O, önce Yakup Bey'in oğlu Cafer Bey'in koruduğu Kemah üzerine hareket ederek burayı ele geçirerek Cafer Bey’i öldürdü. Ancak şartlar Uzun Hasan'ın amcasının üzerine hareket etmesini engelledi (Woods 1993: 144).

Uzun Hasan, Erzincan'1 ele geçirmek için harekete geçmek istedi ise de Diyarbekir taraflarında işlerin karışması üzerine bu tarafa yöneldi. $\mathrm{Bu}$ bölgede işleri tekrar yoluna koyduktan sonra Arapşah'ın üzerine hareket ederek $\mathrm{Kulak}^{27}$ yoluyla yaylak tarafina yöneldi. Bu sirada Arapşah'da Sürmeli ${ }^{28}$ mevkiinde bulunuyordu. Bunun üzerine Uzun Hasan Luhuk, Beğ Sülün ve Hınıs yoluyla Eleşkirt mevkiine vardı. O henüz Sancak $^{29}$ bölgesinde bulunken Pilten Bey'in oğulları onunla

27 Eserde geçen Kulak Erzincan'ın ilçesi Otlukbeli olabilir. Çünkü günümüzde bile halk arasında Otlukbeli için Kara Kulak adı kullanılmaktadır.

28 Iğdır'da Aras Boyunda, Tuzluca-Dehne Boğazı arasındaki Sürmeli Çukuru.

29 Çapakçur ile Kiğı arasında bir yerdir. 
TÜBAR-XXXV / 2014-Bahar / Akkoyunlular ve Erzincan

birleşmişlerdi. Şimdi ise Göynük'de ${ }^{30}$ bulunduğu sırada Musa Bey'in oğlu Şah Ali, ona katıldı. Nihayet Eçmiyadzin-Anı yolu üzerindeki Talın bölgesinde Arapşah'ın hanesini ve bu şehri yağmaladı. Buradan Kağızman'a geçti. Burayı kuşattıktan sonra ele geçirdi. Arapşah'ın burada bulunan mallarını da yağmaladıktan sonra Arapşah'ın bütün askerlerini öldürdü. Burada üç gün kaldıktan sonra Avnik ve Erzurum yöresinden yollarına devam ederek Tercan'a geldiler. Uzun Hasan Erzurum'dan geçerken askerlerinden bir kısmını Bayburt taraflarına gönderdi. Onlar Bayburt'tu yağmaladıktan sonra Tercan'da Uzun Hasan ile bir araya geldiler. Bölge hâkimi Şeyh Mahmud, Uzun Hasan'ın Tercan'a geldiğini haber alınca huzura çıkarak itaatini arz ederek kaleyi ona teslim etti. Bundan sonra Şibge ${ }^{31}$ kalesine Bayındırlı bayrağ 1 dikildi. Burası Pilten Bey'in oğlu İskender Bey'e bırakıldı. Bütün Bayındırlı ordusu Tercan'a gelerek burada toplandı (Tihranî 1993: 235-238). Bayındırlılar, Tercan'da dinlendikten sonra Erzincan'a giderek buray1 kuşattılar. Ancak Kışın yaklaşması üzerine Kışlağa yöneldiler. İlkbaharın gelmesi üzerine tekrar Erzincan üzerine hareket edildi. Ancak Bayındırlılar için önemli yerleşim yeri olan Hasankeyf' in Karakoyunlular tarafından kuşatıldığı haberi üzerine Hasankeyf’e doğru yöneldi (Tihranî 1993: 240; Woods 1993: 146).

Karakoyunlu hükümdarı Cihanşah, yirmi bir süvari ve piyade askerlerini daha önce Erzincan'da hâkim olan Karakoyunlu emirlerinden Emir Arapşah ile birlikte Erzincan taraflarına gönderdi. Arapşah'ın yanında Yakub-i Alpa'ut oğulları ve Ağaçeri boyunun lideri Ali Bey gibi önemli komutanlar da bulunuyordu. Karakoyunlu ordusu Erzincan sınırında Şah Ali Musa'nın hâkimiyetindeki Erzincan'ın güneydoğusunda bulunan Şeteri kalesini kuşattı. Durumun kötüleşmesi üzerine hisar halk1 elçi göndererek durumlarına Uzun Hasan'a bildirdiler. $\mathrm{Bu}$ sırada Hasankeyf'i kuşatmakta olan Akkoyunlu beyi Melik Halef'e 10 men $^{32}$ altın ile 50 men gümüş gönderdi. Ardından da kendisi de yaylağa hareket ederek Batman'a geldi. Emir Arapşah ise Uzun Hasan'in hareket ettiğini haber alınca Şeteri kalesindeki kuşatmayı kaldırarak Erzincan taraflarına yöneldi (Tihranî 1993: 241; Woods 1993: 146).

$\mathrm{Bu}$ sirada Bayburt, Karakoyunlu emirlerinden Mahmud-i Kükeltaş'ın elinde bulunuyordu. O, Bayındırlılara karşı kaleyi korumada

30 Bingöl ile Hınıs arasında bir yerdir. Göynük, yanmış, yanık anlamındadır.

31 Tercan'ın köylerinden birisinin adıdır.

32 Ağırlık ölçüsü. 
çok zorlanıyordu. Durumu Cihanşah'a bildirdiği için Karakoyunlu hükümdarı da Bayburt kalesini Duharlu boyundan başkasına verdi. Mahmud-i Kükeltaş ise Serçeme ${ }^{33}$ üzerinden Cihanşah'ın karargâhına gittiği bir sırada Bayezid Bey'in saldırısına uğrayarak yağmalandıktan sonra esir edildi. Bayezid Bey, onu Erzincan'da esir olan mirza Muhammed-i Tavacı ile değiştirdi. Arapşah ile bazı Karakoyunlu emirleri, bu sırada Uzun Hasan'ın gücünü öğrendikleri için hep birlikte Erzincan'dan hareket ederek Cihanşah'ın yanına gittiler (Tihranî 1993: 241-142).

Uzun Hasan güney bölgelerinde faaliyet gösterdiği bir sirada Erzincan yaylağında bulunan emirlerden kendi bölgelerine gelmesi yönünde haberler alması üzerine Erzincan taraflarına hareket etti. Erzincan'a ulaştıktan sonra şehri ve köylerini yağmaladı. Bu sırada Pilten Bey'in oğlu Halil Bey, Karakoyunlu hükümdarı Cihanşah Mirza'nın saldırmas1 ihtimalinin bulunduğu yönünde uyarıs1 üzerine Uzun Hasan Bey, Tercan bölgesine yöneldi. Buradan da Otlukbeli yolu ile Bayburt yörelerine akında bulunarak yağmaladı. Cihanşah'ın saldırı haberinin yalan olduğunu duyunca da tekrar Erzincan'a geldi. Bölgede geri kalan yerleri de yağmaladıktan sonra Diyarbekir'e gitti (Tihranî 1993: 246-247; Woods 1993: 147). Daha sonra da Cihanşah, Karakoyunlu beylerinin ayrıldığı Erzincan'1 ve Akkoyunluların hükümdarlığının nişanını Akkoyunlu Cihângir Mirza'ya verdiği haberi kendisine ulaştı (Tihranî 1993: 256; Woods 1993: 150).

Daha sonra Akkoyunlu hükümdarlığına getirilen Cihângir Mirza, yardım ve destek almak amacıyla Cihanşah'ın huzuruna geldi. Kışı Cihanşah'ın yanında geçiren Akkoyunlu hükümdarı, baharın gelmesi üzerine yanına Mahmud-1 Elmas ile Ebû'l-Kasım Mirza gibi Karakoyunlu emirlerin katılması ile Erzincan taraflarına hareket etti. Cihanşah, Akkoyunlu hükümdarının yanına Arapşah komutasında on iki bin kişilik bir süvari birliği de kattı. Ordu Erzincan'a varınca Uzun Hasan, savaş için hazırlıklara başladı. Onun bu hareketi Karakoyunlu emiri Arapşah'1 korkutmuş ve hükümdarına gönderdiği haberde bunu açıkça belirtmiştir. Onun kaçmasından sonra Cihângir, oğlu Murad'1 Erzincan'a yerleştirerek Mardin'deki kalesine döndü. Arapşah ise İspir tarafina yönelerek burada çok şiddetli bir yağmada bulundu. Bunun üzerine emir Bayezid-i İspirî, Uzun Hasan'a gönderdiği haberde, onun yaptığı yağmanın korkunçluğunu dile getirmiştir. Uzun Hasan, yanında

33 Erzurum'un kuzey batısındaki Serçeme köyü. Bu isim Azerbaycan kültür sahasında çokça kullanılmaktadır. 
TÜBAR-XXXV / 2014-Bahar / Akkoyunlular ve Erzincan

Mihmad Bey, Pilten Bey'in oğlu Halil Bey ve Şeyh Hasan ile birlikte Arapşah'ın üzerine hareket etti. Bunun üzerine Arapşah kaçarak Hoy'a gitti. Uzun Hasan ise Pasinler'i (Hasankale) yağmaladıktan sonra burada bir hafta kaldıktan sonra Harran vilayetine gitti (Tihranî 1993: 259-260; Woods 1993: 150).

Uzun Hasan Bey, çok geçmeden tekrar Erzurum taraflarına geri dönerek Tercan'a ulaştı. Burada Akkoyunlu hükümdarı ve Uzun Hasan'ın kardeşi Cihângir Mirza, Uzun Hasan'a bağlı olan orduya saldırdı. Bunun üzerine Uzun Hasan, Halil-i Tavacı ile birlikte Şeyh Hasan'1 orduyu korumaya gönderdikten sonra kendisi de Erzincan'a gitti. Emir Bayezd-i İspirî, Hurşid Bey ve Kemah ordusu da ona katıldı. Uzun Hasan, Erzincan açıklarına inen Akkoyunlu ordusuna kuşatma konusunda gerekli emirleri verdikten sonra Diyarbekir tarafina gitti. Ordu mensupları ise Cihângir Mirza'nın saldırısından korktukları için Uzun Hasan'ın yanına gittiler (Tihranî 1993: 261). Uzun Hasan, Daha sonra Erzincan yörelerine gelerek şehri ele geçirdi ve yönetimini de Hurşid Bey'e bıraktı (Tihranî 1993: 281; Hasan Rumlu 1931: 359).

1457'de Diyarbekir'in doğusunda yapılan savaşta Cihângir Mirza'nın kardeşine yenilmesi üzerine kardeşi Uzun Hasan'a Akkoyunlu Devleti'nin hükümdarlığını bıraktı. Diğer kardeşi (Celâyirli Sultanlarından birinin de adı olan) Üveys de artık Uzun Hasan'ın hükümdarlığını tanıması üzerine kendisine yeniden Ruha valiliği verildi. Erzincan'ın da Bayezid Bey'in oğlu Hurşid Bey'e bırakılması üzerine yaylak ve kışlakların artık tek bir elde toplandı.

\section{KAYNAKÇA}

ANDREASYAN, Hrand D. (1975), "XIV. ve XV. yüz yıl Türk Tarihine Ait Ufak Kronolojiler ve Kolofonlar", İstanbul Üniversitesi Tarih Enstitüsü Dergisi, S. III, s. 83-248.

Aziz b. Erdeşir-i Esterabadî (1928), Bezm u Rezm, (Yay.: Kilisli Rıfat), İstanbul.

CÖHÇE, Salim (1997), "Otlukbeli Savaşına Kadar Akkoyunlular”, Anadolu Birliğinin Sağlanmasında Otlukbeli Savaşının Yeri ve Önemi Panel Bildirileri, (Hzl. Prof. Dr. Enver Konukçu), Otlukbeli Belediyesi Yayınlar1 s. 125.

Ebu Bekr-i Tihranî (1993), Kitab-ı Diyarbekriyye, I, (Yay. N. Lügal, F. Sümer),TTK, Ankara.

Hasan-1 Rumlu (1931), Ahsenü't-Tevarih, (Yay. C. N. Seddon), Baroda. 
TÜBAR-XXXV / 2014-Bahar / Ahmet TOKSOY

HINZ, Walther (1992), Uzun Hasan ve Şeyh Cüneyd, (Çev. Tevfik Bıyıkoğlu), TTK, Ankara.

İSMAYİLOV, Mahmud (1991), Kara Yusuf, Bakü.

KAHRAMAN, B. (2009), "Vahîd Mahtumî Dîvanında Görülen Bir Terim", Türkiyat Araştırmaları Enstitüsü Dergisi, S. 39, s. 506.

KONUKÇU, Enver (1998), Otlukbeli Meydan Savaşı, Erzincan Belediyesi Yayınları Ankara.

KONUKÇU, Enver (1998), “Tercan Tarihi”, Cumhuriyetin 75. Yılında Tercan, Tercan Belediyesi yayınları, Ankara.

KONUKÇU, Enver (1994), “Clavijo'nun Doğu Anadolu (Erzincan-Doğu Bayezid) Yolculuğu 1404-1405)”, TTK Yayınları, Ankara.

Müneccimbaşı (1285), Sahaifü'l-Ahbar, İstanbul.

Nizamüddin Şami (1987), Zafername, (Çev. Necati Lugal), TTK, Ankara.

SANJIAN, Avadis K. (1969), Colophons Of Armenia Manuscripts 1301-1480, Cambridge.

TEKİNDAĞ, Şehabeddin (1961), Berkuk Devrinde Memlîk Sultanlı̆̆g, İstanbul Üniversitesi Edebiyat Fakültesi yayınları, İstanbul.

UZUNÇARŞILI, İ. Hakkı (1968), "Sivas ve Kayseri Hükümdarı Kadı Burhaneddin Ahmed”, Belleten XXXII/125-128, Ankara, s. 191-244

WOODS, John (1993), 300 Yıllık Türk Imparatorluğu Akkoyunlular, (Çev. Sibel Özbudun), Milliyet Yayınları, İstanbul.

YİNANÇ, Mükrimin Halil (1944), “Cihanşah”, İslam Ansiklopedisi, III, Milli Eğitim Bakanlığı Yayınları, İstanbul.

YÜCEL, Yaşar (1991), Anadolu Beylikleri Hakkında Araştırmalar II, TTK, Ankara.

YÜCEL, Yaşar (1986), “Fatih'in Trabzon'u Fethi Öncesinde Osmanl1-TrabzonAkkoyunlu İlişkileri”, Belleten, XLIX/193-195, Ankara, s. 287-312. 